\title{
Based on the "Internet plus" era of enterprise management innovation path exploration
}

Jian LI

Qilu Normal University, China Shangdong 250013

\begin{abstract}
The world has entered the information age, all kinds of information technologies such as cloud technology, big data technology are in rapid development, and the "Internet plus" appeared. The main purpose of Internet plus "is to provide an opportunity for the further development of the enterprise, the enterprise technology, business and other aspects of factors combine. For enterprises, grasp the "Internet plus" the impact of the market economy will undoubtedly pave the way for the future development of enterprises. This paper will be on the innovation path of the enterprise management Internet plus "era tied you study, hope to be able to put forward some opinions and suggestions.
\end{abstract}

Keyword.Internet plus;Business management;Innovation exploration

\section{Introduction}

"Internet" was made by the chairman of the board of directors of the Tencent and CEO Ma Huateng. In the eyes of many people, "Internet plus" may have a certain degree of current business impact, on the contrary, the promotion of traditional industrial production technology and management mode of the continuous upgrading from some aspects. The so-called "Internet plus" actually refers to a new form of market economy, it will be the Internet and social economy to create with reasonable configuration and integration of [1] production factors and resources of the enterprise to take advantage of the internet. This will greatly improve the cohesion of enterprise, but also in the Internet and all kinds of advanced research and production technology integration, the formation of a broader "Internet plus" form of economic development. At present, the application of Internet plus "has been more and more widely, so enterprises should take advantage of this opportunity, the management mode of the corresponding change, to adapt to the future there will be a wave of industry changes.

\section{1 "Internet plus" for enterprises}

"The birth of Internet plus" can be said to cause a tremendous impact on the enterprise, because it makes the operation mode and management mode of enterprises have changed greatly. First of all, in the traditional business activities, although the service object should occupy a high position, but due to various factors, it is difficult to achieve. Customer service evaluation can not play its due role, it is difficult for customers to communicate fully, which makes the enterprise services and customer needs are out of touch. "Internet plus" is a better solution to this problem. Such as the catering and entertainment industry have many in the use of "beauty", the use of every customer will use mobile phone as a medium, collecting customer feedback on the service enterprise, also between the customer can also communicate with each other to give service unit a fair evaluation. So that enterprises can not only products as the main competitive point, if not change can not be in the current fierce competition in the market to occupy a place. Second, because the Internet has a strong openness, business management framework can also produce a certain change. The traditional mode of enterprise 
management is to take from the top to the bottom of the pyramid management framework. In this way, the decision-making right of enterprises into the hands of a few people, some grass-roots workers unable to put forward valuable suggestions by combining their own experience and the development of the enterprise. The application of "Internet plus" will change the status, the customer service personnel from the nearest base for the enterprise development planning, bring the whole enterprise reform.

\section{2 "The opportunities and challenges Internet plus" for enterprise development}

"Internet plus" can be said to bring great convenience for the development of various enterprises at present, enterprises can rely on the Internet for their potential for development, expand the scope of business, improve brand competitiveness. But this also means that enterprises must be based on the relevant characteristics of the Internet to reform management mode, if you can not follow the direction of market economic development, it is bound to be left behind by other companies.

\section{1 "Internet plus" has brought opportunities for the development of enterprises}

The emergence of the Internet makes consumption more diversified, people at home can browse to the hundreds of millions of different kinds of commodity information, can also according to the evaluation of other consumers of a certain brand has a more intuitive understanding. Not only that, the use of the Internet can reduce the cost of physical stores, greatly reducing the cost of work. With the continuous development of e-commerce, the market operation mode Internet plus "increasingly mature, this also leads to the traditional market share continued to decline, all kinds of products, business model, business channels and marketing methods will produce some changes. The current world is in the information age, people for computers, electronic equipment, communications and other technology needs more. Although the "Internet plus" is the basis of market business model change, but to some extent, change the model of market economy indirectly promoted the upgrading of products of all kinds of information and use. It can be said that the use of electronic information technology and business marketing model has a good interaction between the transformation. Although the current our country market economy mode is not fundamentally change, but we can still rely on it in promoting the development of various traditional enterprises, network and economy closely integrated to form a new industrial chain. Still in the current food and beverage industry, for example, different customers demand for services is not the same, but in the past it is difficult to get effective information before the official consumer spending. But now it is different, customers can make full use of the network has been a large number of customers have been consumed by the evaluation to understand the characteristics of its services, and further determine whether it can be accepted. If you are not satisfied with the service, but also through the Internet for complaints and evaluation of enterprises play a good role in promoting.

\section{2 "Internet plus" for enterprise development challenges}

First of all, the current enterprise management concept is not completely. Our country's enterprise management work is in the reform and opening up after the official. Just a few decades of time is not enough to make our country's enterprise management has the perfect idea, so that our country's management theory is only from abroad for reference. But "Internet plus" requirement is the enterprise to customer service as the business center of the enterprise, the traditional business management theory "to the interests of the enterprise as the center" on the contrary. If you can not solve this problem, it is difficult to form a match with the "Internet plus" management style, efforts will be cast to the wind.

Secondly, the current enterprise management structure and management mode is more obsolete. In order to be able to Surety Company centralization, most of the management structure of the enterprise is Pyramid, the management of the enterprise only by a few people at the top of Pyramid. But the real exposure to corporate customers, to understand the needs of customers are often at the grassroots level of Pyramid staff, which may lead to the management and business development needs of the actual need to be separated from each other. It can be said that the traditional enterprise management structure is difficult to deal with the current market environment, the information transmission speed is too slow will become the biggest 
drawbacks of enterprise development. Not only that, the enterprise of our country because of the influence of the planned economy is difficult to carry on the thorough reform and the innovation, thus receives the certain degree the restraint. For example, in the past, companies only need to send advertising can be better to complete the work of enterprise product marketing. But now is twenty-first Century, the simple use of advertising marketing is far from enough. If the customer can not get enough information from the marketing, they will not choose to consume. Therefore, most of the current enterprise management structure and management model is not able to meet the market development needs of the information age.

Finally, the enterprise talent management work is not attached importance to. For enterprise management, how to recruit high-quality talent and retain high-quality personnel is the most important. In the past business management, the more excellent people tend to be more rigorous treatment, which is the current "people-oriented" management approach. Even in a short period of time to allow employees to create wealth, but also lose the loyalty of employees. Therefore, to take appropriate measures for human resources management is particularly important, only pay attention to the communication between management and employees, to establish a bridge of mutual attention, in order to improve the working efficiency of the staff.

\section{3 "Enterprise management innovation path Internet plus" era}

Through the enterprise management of the "Internet plus" era we can see, to carry on the innovation of enterprise management mainly need to proceed through the following aspects.

\subsection{Innovative enterprise management concept}

Enterprise management concept is the basis of enterprise management, it can be said that all the work of the enterprise management will be around the idea of the management of enterprises to carry out. In the "Internet plus" era, customers for the enterprise means more and more important. Whether the enterprise can have a strong and comprehensive competitiveness in the current market environment depended on not only in the traditional enterprise capital strength, power and other technical factors, customers to create the effect of relatively more important. This will require the enterprises "to their own interests as center" management philosophy to "in order to meet the actual needs of customers" management philosophy, and in work pay attention to the connection between the client and the, construction of active cooperation, openness and win-win cooperation environment. This can allow enterprises to develop the dominant direction of the customer, to achieve the effective development of the market environment.

\subsection{The innovation of management structure and management mode}

Restrict the further development of enterprise management structure greatly on the shape of the Pyramid enterprises, the news spread slowly makes it difficult to respond to market changes. However, in the "Internet plus" era, which is one of the most fatal flaw. Therefore, enterprises must change the management structure, reduce the management of no great importance, so that between the grass-roots workers and decision-making and communication more efficient. This can be said to be a Pyramid shaped flat management structure, not only can accelerate the speed of decision-making, but also can eliminate the influence of working pressure on the enthusiasm of the staff of the class. In addition, enterprises also need to innovate management model, the Internet technology is applied to them, the use of new management tools to carry out the production, marketing and transportation and other aspects of the enterprise. This not only can improve the level of business, to speed up the pace of customer demand response, but also to improve customer satisfaction, have a stronger market competitiveness.

\subsection{Innovative talent management mechanism}

According to the previous analysis we can see, talent for enterprise development has a crucial role, but past enterprise talent management mechanism will only compress to a great extent on the staff of the enthusiasm, greatly affected the efficiency of the work of the various departments of the enterprise. Such a talent management mechanism is undoubtedly a failure, because it can not stimulate the enterprise employees to devote to the work of the work, to create more wealth for the enterprise value. And this management mechanism was too strong, so that 
employees tend to have psychological conflict. Therefore, the management mode of enterprise development to flexibility is necessary. The so-called flexible management is to take the "people-oriented" concept of talent management, by all the production activities of enterprises by the staff to complete all must, therefore the staff should be the foundation of enterprise development. Therefore, the enterprise in the management of staff need to consider to staff the dignity and get sufficient attention, only in this way to let the staff have relatively strong sense of belonging, to enhance the cohesion of all the staff inside the enterprise.

\section{Epilogue}

With the application of information technology in people's lives more and more widely, the Internet for the impact of the major enterprises in the market is also growing. For the current enterprises, "Internet plus" era can be said that if the enterprise can There are both advantages and disadvantages., innovation of enterprise management under the current market situation, so they can allow enterprises to further development; but if the enterprise still complacent, followed the old management mode and management concept, a large wave that will be difficult to survive the market changes.

\section{References}

Feng Yanwei [1]. Green logistics problems and countermeasures in the development of research in China [J]. Journal of commercial economy, 2013, (9) : 242-245. [2] weeks. Green of green logistics management, the role of environmentalmanagement system in modern green logistics analysis [J]. Journal of transportation enterprise management, 2013, 10 (3) : 105-108

[3] gao jie analysis of modern green logistics management strategy [J]. China's foreign trade business, 2013, 12 (8) : 156-159 